IZA DP No. 9537

Women at the Top in Developing Countries:

Evidence from Firm-Level Data

Khalid Sekkat

Ariane Szafarz

Ilan Tojerow

November 2015 


\title{
Women at the Top in Developing Countries: Evidence from Firm-Level Data
}

\author{
Khalid Sekkat \\ Université Libre de Bruxelles (ULB), Centre Emile Bernheim (CEB)
}

Ariane Szafarz

ULB, SBS-EM, CEB and CERMi

Ilan Tojerow

ULB, SBS-EM, CEB, DULBEA and IZA

\section{Discussion Paper No. 9537 \\ November 2015}

\author{
IZA \\ P.O. Box 7240 \\ 53072 Bonn \\ Germany \\ Phone: +49-228-3894-0 \\ Fax: +49-228-3894-180 \\ E-mail: iza@iza.org
}

Any opinions expressed here are those of the author(s) and not those of IZA. Research published in this series may include views on policy, but the institute itself takes no institutional policy positions. The IZA research network is committed to the IZA Guiding Principles of Research Integrity.

The Institute for the Study of Labor (IZA) in Bonn is a local and virtual international research center and a place of communication between science, politics and business. IZA is an independent nonprofit organization supported by Deutsche Post Foundation. The center is associated with the University of Bonn and offers a stimulating research environment through its international network, workshops and conferences, data service, project support, research visits and doctoral program. IZA engages in (i) original and internationally competitive research in all fields of labor economics, (ii) development of policy concepts, and (iii) dissemination of research results and concepts to the interested public.

IZA Discussion Papers often represent preliminary work and are circulated to encourage discussion. Citation of such a paper should account for its provisional character. A revised version may be available directly from the author. 
IZA Discussion Paper No. 9537

November 2015

\section{ABSTRACT \\ Women at the Top in Developing Countries: Evidence from Firm-Level Data}

This paper uses worldwide firm-level data to scrutinize the governance factors that favor gender diversity in leadership positions. Our results reveal that the gender of the dominant shareholder is key. The chief executive of firms with a female dominant shareholder has a significantly higher probability of being a woman than in other firms. The effect is even more pronounced when the female shareholder holds a higher share of the capital and when the firm is foreign-owned. Our results suggest that "old boys' club" ownership structures are a major impediment to the empowerment of female talent in developing countries.

JEL Classification: O15, J71, G32, M51, D22

Keywords: gender, diversity, ownership, leadership, CEO, development

Corresponding author:

Ilan Tojerow

Université Libre de Bruxelles

Solvay Brussels School of Economics and Management

50, Av. F.D. Roosevelt

CP $114 / 02$

1050 Brussels

Belgium

E-mail: itojerow@ulb.ac.be 


\section{Introduction}

Economic development rests heavily upon the effective utilization of talent ${ }^{1}$ by corporations. Since talent is scarce, especially in developing countries (Schuler et al., 2011), any waste of it may be costly, not only to the firms but to the whole economy. ${ }^{2}$ Beyond fairness concerns, therefore, discriminatory practices, glass ceilings and other impediments to talent utilization may be detrimental to economic development. This paper wonders whether factors linked to ownership and corporate governance might explain why some firms in the developing world are more reluctant than others to hire female chief executive officers (CEOs). We concentrate specifically on ownership characteristics. Using worldwide firm-based data from the World Bank, we discover that one key factor relates to the gender of the dominant shareholder. All else equal, when the dominant shareholder is a woman, the CEO is also much more likely to be a woman. The effect is even more pronounced when the dominant shareholder holds a higher share of the capital and when the firm is foreign-owned. Our results suggest that "old boys' club" ownership structures are a significant barrier to the empowerment of female talent in developing countries.

Ownership is dominated by men. For instance, in the U.K. in 2004 a meager $15 \%$ or so of enterprises were female-owned (Carter and Marlow, 2006). Even in the U.S., often cited as a model to emulate, women-owned firms accounted for only $28 \%$ of all businesses (Carter and Marlow, 2006). Little evidence for developing countries is available. Exceptions include the study by Bruhn (2009), which shows that while the percentage of female-owned firms is relatively high for micro-enterprises in Latin $\mathrm{America}^{3}$ (although lower than 50\%, except in

\footnotetext{
${ }^{1}$ Talent refers to workforces with high level of human capital. This expression emerged in the late 1990s when the McKinsey consulting firm mentioned "the war for talent" (Vaiman et al., 2012). According to Hewlett and Rashid (2010), discriminatory behaviors present a major problem for multinational companies, which rely on talent to fulfill their growth expectations on emerging markets.

${ }^{2}$ The literature on the demography of organizations shows that talent is not randomly assigned (Williams and O'Reilly, 1998). In particular, talent is attracted by diversity (Florida, 2002).

${ }^{3}$ More precisely, the study is about Argentina, Bolivia, Brazil, Ecuador, Honduras, Mexico, Peru and Uruguay.
} 
Honduras), it never reaches $20 \%$ for larger businesses. According to the figures in the 2014 Global Entrepreneurship Monitor report, the same is true of many other developing countries.

Although gender diversity in the top management is recognized as a potential driver of firm performance (Oakley, 2000; Krishnan et al., 2005; Smith et al., 2006), the lack of women in leadership positions is one of the most persistent features of today's corporate world. This holds true in both developed and developing countries. ${ }^{4}$ Even countries at the cutting edge of women's rights, such as those in Scandinavia, feel compelled to impose quotas in order to raise the proportion of women in the boardroom (Pande and Ford, 2011). The mistrust of female CEOs is objectivized by Lee and James (2007), who find that U.S. investors' reactions to the announcements of women CEOs are significantly more negative than in the case of their male counterparts. In emerging countries, the situation is worse. Weak legal protection is often associated with explicitly discriminatory behaviors in the workplace (Hewlett and Rashid, 2010). Muravyev et al. (2009) provide evidence that the gender gap in access to finance for entrepreneurs is inversely related to the country's level of financial development. The authors interpret their findings as consistent with taste-based discrimination.

Profit-seeking alone is insufficient to combat efficiently the under-utilization of female talent in corporations (Rosén 2003; Méon and Szafarz, 2011). The empirical literature confirms that gender discrimination persists in the labor market (Altonji and Blank, 1999; Blau and Kahn, 2000). Evidence reveals the existence of a trade-off between the economic cost of discrimination (Becker, 1957), and the psychological cost that bigoted shareholders face when hiring employees from groups they dislike. In particular, the social affinity theory postulates that employers feel more comfortable hiring people with whom they share characteristics, such as gender (Dillingham et al., 1994; Szafarz, 2011). In modern corporations, however, the

\footnotetext{
${ }^{4}$ According to Pande and Ford (2011), the average share of women in the board of directors is $11.9 \%$ in Europe, 9.9\% in the Americas, $6.5 \%$ in the Asia-Pacific region, and 3.2\% in the Middle East and North Africa.
} 
involvement of shareholders in the hiring of top managers varies; in consequence, not only the size of the firm and its governance structure should matter, but also the power and characteristics of any dominant shareholder.

According to the gender affinity hypothesis, ${ }^{5}$ a female dominant shareholder would prefer to hire a female CEO. So far, the hypothesis has not been tested under this specification. Actually, little is known about the impact of shareholders' genders on the gender-friendliness of their corporations. The few studies analyzing the impact of the employer's gender on the promotion and pay of female employees proxy the employer's gender by that of the firm's CEO or top manager. In this stream of literature, Bell (2005) and Cardoso and Winter-Ebmer (2010) find that female employees are better treated in female-led firms. These results lend credence to the gender affinity hypothesis. The impact is, however, limited to fair readjustments in gender gaps, since no discrimination against male employees has been documented.

So far, the influence of the gender of the dominant shareholder, if any, remains unexplored. This paper fills the gap by exploiting a World Bank database of detailed information on more than 30,000 firms active in 74 developing countries over the 2009-2012 period. Our results reveal that the presence of women among shareholders has a strong impact on the probability of having a female CEO. This outcome remarkably resists a substantial collection of robustness checks and extensions of the estimated probit model. In sum, our empirical exercise suggests that gender affinity in the $\mathrm{C}$-suite is a major driver for supporting female talent in developing countries

\footnotetext{
${ }^{5}$ The gender affinity effect (or "women for women") stems from political science. In particular, scholars have shown that in U.S. elections women tend to vote for female candidates (Brians, 2005; Dolan, 2008). Interestingly, Dillingham et al. (1994) observe from votes in a professional association that the same-gender preference is stronger among women than among men.
} 
The remainder of the paper is organized as follows. Section 2 presents the theoretical background on female corporate leadership. Section 3 describes our dataset while Section 4 is devoted to the empirical analysis. Section 5 includes robustness checks and extensions. Section 6 concludes.

\section{Theoretical Background}

Our topic of interest lies at the intersection of three fields: development, corporate governance, and gender studies. Even though development levels and cultural gaps can seriously interact with corporate governance mechanisms, our literature review includes evidence from both the South and the North, while prioritizing articles dealing with the developing world.

Research on female corporate leadership in developing countries is limited. Plausibly, this is because the scarcity of female corporate leaders makes it difficult to address gender matching empirically (Fine, 2009). Exceptions include the recent study by Navarro and Gallo (2014), who uncover the positive effect that female CEOs have on performance. Using a worldwide database, the authors show that female CEOs take less risk than their male counterparts, but they increase job opportunities for women. Hypothetically, women leaders in developing countries lack support from their colleagues and subordinates, and this has a negative effect on their business performances. To test the lack-of-support hypothesis, Field et al. (2014) invite a random sample of customers of India's largest women's bank to attend business counseling with a friend. The authors observe that the presence of the chosen accompanying person has a significantly positive impact on both business success and household income. The effect is even more pronounced among clients from restrictive social backgrounds. Field et al. (2014)'s findings are in line with the hypothesis that women lack on-site peer support. In the context of hybrid organizations, namely financial cooperatives in Senegal, Périlleux and Szafarz (2015) 
show that female CEOs actively support the social objectives of female-dominated boards. In contrast, male CEOs associated with female-dominated boards tend to mitigate the social outcomes aimed at by their boards. The problem is that, in the field, only $20 \%$ of femaledominated boards are associated with a female CEO. Therefore, one should not confuse women's motivation with their ability to affect decision-making (Das, 2014).

Evidence on gendered leadership in developed countries is also relevant to our purpose. Using a linked employer-employee dataset on German firms, Gagliarducci and Paserman (2014) study the interaction between the gender compositions of the top two layers of management. They observe that women in the top layer exhibit worse business performances than their male counterparts, but only when surrounded entirely by men. The impact is reversed as the share of women in the second layer of management increases, a finding consistent with male employees being reluctant to work in a women-led environment. Hence, for women leaders who anticipate this sort of behavior from their male subordinates, a preference for hiring females makes perfect sense. This attitude could also explain why gender affinity is more a female story than a male one. If female subordinates work equally well under the authority of men and women, thentaste aside-male leaders have no rationale for preferring male subordinates over female ones. In a study on family-controlled Italian firms, Amore et al. (2014) find that the number of women sitting on the board has a positive impact on the operating profitability of female CEOs. The effect is reduced for large firms and those located in regions with prevalent gender prejudices. Arguably, the impact of female board members depends on their perceived strength within the firm. Flabbi et al. (2014) confirm that the performance of female-led firms increases with the share of female employees.

Overall, gender affinity appears to be a major driver of corporate female leadership. However, there are two (non-mutually exclusive) ways to theorize gender affinity in corporations. The first - and probably most obvious — one refers to homophily, i.e., the preference for people 
sharing characteristics with oneself. For instance, Westphal and Zajac (1995) rely on an assortative-matching model to explain that powerful CEOs in Fortune/Forbes 500 companies manage to appoint new board members who are demographically similar to themselves. In addition, the authors document that similarity between the CEO and the board leads to higher CEO compensation. The second approach to gender affinity introduces rational motivations explaining why women would rationally benefit from working with same-sex colleagues and subordinates. Typically, the reasons stem from the fact that (some) men in the workplace behave in a way that can harm their female colleagues and supervisors. Most of the literature tends to endorse the second view. Precisely, the "women for women" preference could simply result from female leaders' professional ambition rather than from homophily. Still, in situations where same-gender solidarity is less profitable, the reverse pattern ("women against women") may occur. In particular, the so-called queen bee syndrome (Staines et al., 1974) refers to female leaders who make career progress more difficult for other women. ${ }^{6}$ Last, gender affinity could stem from the reduction in asymmetric information that results from professional interactions between same-sex agents. Cornell and Welch (1996) develop a model that opposes taste-base discrimination à la Becker (1957) to "screening discrimination", where an employer can make a more accurate judgment of job applicants belonging to the same population group as he or she does. In particular, the model predicts that screening discrimination is more probable in sectors where skill is harder to observe. Bostic (2003) transposes this sorting problem to the credit industry. Regardless of the market of interest, this stream of literature suggests an interpretation of cultural (or gender) affinity as relating to a "common bond" that makes it easier to assess same-group applicants.

\footnotetext{
${ }^{6}$ Sheppard and Aquino (2014) claim that women's same-sex conflict is overly problematized. Bednar and Gicheva (2014) make the case for going beyond gender matching in mentoring relationships.
} 
Ownership features other than gender affinity can contribute to the empowerment of women leaders. Olcott and Oliver (2014) note that foreign takeover has a positive impact on prospects for women in Japan. Possibly, however, this outcome is specific to that country, where the percentage of female managers is very low by developed-economies standards. Using data from Korea, Siegel et al. (2010) show that firms with foreign ownership are keener than local ones to exploit opportunities associated with hiring women and discriminated-against minorities. Heyman et al. (2013) observe that the competitive pressure following mergers and takeovers can bring about an increase in the share of female staff. These results confirm the findings of Black and Strahan (2001) showing that prior to deregulation, banks were able to discriminate against women in rent sharing. ${ }^{7}$ Hirsch and Mueller (2014) show that Germany's owner-run firms exhibit higher gender pay gaps than manager-run firms. However, the authors attribute their results to differences in leadership models rather than to discrimination.

In sum, evidence originating chiefly from developing countries tends to support the hypothesis that female ownership has a positive influence on the incidence of female CEOs. However, it is premature to jump to conclusions: not only are the observations dispersed in time and space, but the econometric methods are barely comparable and authors interpret their findings in different ways. Consequently, there is room for a large-spectrum international study with the ambition to contribute to expand knowledge on worldwide gender affinity in leadership. The Enterprise Surveys collected by the World Bank probably constitute the first database that can be used to perform such a study in developing countries.

\footnotetext{
${ }^{7}$ Rycx and Tojerow (2004) and Navon and Tojerow (2013) highlight the importance of rent sharing in explaining gender discrimination (by showing that the gender wage gap in less profitable firms is partly attributable to the segregation of women.
} 


\section{Data and Descriptive Statistics}

\subsection{Data}

Our empirical analysis is based on a set of comparable country firm-level surveys, the Enterprise Surveys. These surveys resulted from a World Bank initiative aimed at collecting comparable firm-level information from more than 100 countries concerning the management and financing characteristics of companies as well as business environment issues related to corruption, infrastructure, crime, competition, and performance measurement. The Enterprise surveys assess firms of all ownership types, sizes and sectors. Together they form the first extended country-comparable firm-level collection of reliable data sourced directly from owners and top managers, using the same methodology and offering global coverage of developing economies. Hence, the Enterprise Surveys allow a detailed analysis, both across and within countries, of the gender ownership structure within firms and the impact of the top manager's gender. ${ }^{8}$

Altogether 31,541 firms in 74 countries were polled across a three-year period from 2008 to 2012. ${ }^{9}$ Central for our research questions, our sample contains detailed information on ownership, including concentration, private/public composition, and gendered structure. The gender dimension is captured through two variables that are seldom available in surveys. First, the presence of females among the owners is given for all the firms in our dataset. Second, when relevant, the surveys indicate the sex of the largest owner. The second variable overcomes a significant limitation of the first insofar as it provides information on the magnitude of female empowerment within the firm ownership. This information is, however, available only for a

\footnotetext{
${ }^{8}$ See www.enterprisesurveys.org for more details.

${ }^{9}$ See Table A1 in the Appendix for details on the sample composition broken down by country.
} 
subsample of firms located in African countries. In addition, the dataset includes characteristics of the firm (size, legal status, sector) and its CEO (gender and work experience). ${ }^{10}$

\subsection{Descriptive Statistics}

Table 2 presents the sample statistics both globally and broken down by subsamples of interest. In the first subsample, we exclude firms owned individually by a single woman to eliminate cases where the owner is also the CEO. For a similar reason, the second subsample focuses only on firms with more than five employees. Last, descriptive statistics are given for firms in three specific segments: firms with less than $50 \%$ of public ownership, firms with foreign ownership below $50 \%$, and firms with no owner above $50 \%$. These same groups are used in the empirical section.

In the full sample, $16 \%$ of the firms have a female CEO and $39 \%$ of them have a female among their owners. The percentage of women CEOs is relatively stable (and below 20\%) across subsamples. One notable exception concerns the firms with female owners, where the percentage reaches $30 \%$, suggesting a connection between female ownership and female leadership.

[Table 1]

Table 1 also indicates that $27 \%$ of the firms in our sample are sole proprietorships; only $9 \%$ have a share of foreign ownership above 50\%; and 65\% have a dominant shareholder (holding over $50 \%$ of the shares). Most of the firms are located in Latin America. The manufacturing sector is the most frequent.

[Table 2]

\footnotetext{
${ }^{10}$ Table A2 in the Appendix provides a detailed description of all the variables.
} 
Table 2 reports the results of tests of equal means for firms with female and male CEOs, respectively. Firms with a male CEO tend to be larger, older, and more resistant to managerial turnover than those led by a female. Interestingly, the presence of female owners is significantly more likely in firms with a female CEO.

[Table 3]

Table 3 breaks down by country the percentages of firms with a female CEO and with female owners. The figures exhibit wide variations across regions and countries. In the former Communist bloc, the number of female-led firms varies between less than $10 \%$ in Azerbaijan and around $30 \%$ in Belarus and Latvia, while the percentage of firms with female owners is insignificant in Azerbaijan, but very high in Kyrgyzstan (61\%). In Latin America, the average percentages are low, with Chile and Argentina having less than $10 \%$ of female-led firms, as opposed to Nicaragua with more than $25 \%$. Africa is the only region where several countries, such as Angola, Botswana and Rwanda, have absolutely no firms with female owners. However, the overall average female ownership share is similar to that of other regions. In contrast, the African percentages of female CEOs are extremely low, and the average- $13 \%$-is by far the lowest in the world. Only three African countries (Lesotho, Liberia and Rwanda) reach the $20 \%$ threshold. With $19 \%$ of female-led firms and $44 \%$ of firms with female owners, the figures for Asia resemble those for the former Communist bloc.

The regressions in the next sections will investigate whether the variations in female ownership can explain the prevalence of female leadership, while controlling for firm-specific and country-specific variables. 


\section{Empirical Analysis}

\subsection{Estimation Strategy}

To explore the relationship between ownership characteristics and the CEO's gender, we estimate a probit model explaining the likelihood of having a female top manager in the firm. The model has several variables relating to female ownership and controls, which include industry and country dummy variables. It is written as:

$\operatorname{Prob}\left(\mathrm{CEO}_{i}=1\right)=f\left(\right.$ FemOwner $_{i}, E_{i}$, Sector $_{i}$, Country $\left._{i}\right)$

where $C E O_{i}$ is a dummy variable taking value 1 if firm $i$ 's CEO is a woman, and 0 otherwise; FemOwner $_{i}$ is a dummy variable taking value 1 if firm $i$ has a female owner, and 0 otherwise; $E_{i}$ is the CEO's experience (in years); Sector $_{i}$ denotes the sector-fixed effect (17 sectors covering both manufacturing and services); and Country $y_{i}$ is the country-fixed effect.

To robustify our approach, we run the estimation of Eq. (1) on both the full sample and several sub-samples. The first subsample excludes the sole-proprietorship firms with a female owner. This exclusion is meant to address the potential bias attributable to the presence of firms in which the female owner and the female CEO coincide. Our second subsample excludes firms with more than five employees to bypass family firms, where a family connection between the CEO and the owner(s) is probable. Both these subsamples dismiss firms for which the distinction between shareholders and manager is blurred.

We also consider three subsamples that exhibit special ownership characteristics that can interfere with gender considerations. First, we handle the subsample made up of firms with public ownership below 50\%, because public and private sectors do not necessarily share the same employment policies. Second, we use the subsample that excludes firms with more than $50 \%$ foreign ownership. There is an abundant literature showing that foreign-owned and 
domestic firms exhibit different behaviors (see, for instance, Vishwasrao and Bosshardt, 2001). Here, the idea is to acknowledge that foreign ownership can mitigate the impact of local culture, including governance characteristics (Lensink et al., 2008) and gendered aspects (Olcott and Olivier, 2014). The third ownership dimension we explore relates to the dispersion of ownership. If ownership is dispersed, each individual owner, male or female, has less impact on the firm's management. We run the regression in Eq. (1) on the subsample of firms without a majority owner.

Once the likelihood of gender affinity in the owner-manager relationship is high enough, we turn to understanding its emergence. Along the lines of the cultural affinity theory proposed by Cornell and Welch (1996) and Bostic (2003), we oppose taste-based to common-bond gender affinity. In our context, taste-based affinity would mean that female owners prefer to interact with women CEOs more than male owners do, while common-bond gender affinity would correspond to owners of firms making a more accurate assessment of the skills of same-sex CEOs. To oppose these two types of gender affinity we run new regressions, including interactions between sector and female ownership. Stronger impact in more feminized sectors would suggest that the common-bond hypothesis substantiates our findings rather than the testbased one. Practically, we test differences across sectors by adding to Eq. (1) interaction terms between female ownership and sectoral affiliation.

Last, since we include country-fixed effects in all specifications, our results should be understood as explaining country-specific variations in female leadership.

\subsection{Regression Results}

Table 4 presents the estimation results for all the probit specifications introduced in sub-section 4.1 to estimate the impact of female ownership on the prevalence of female CEOs. Our coefficients of interest lie in first row of Table 4. Importantly, regardless of the specification, 
the coefficients are all significantly positive at the $1 \%$ level, suggesting that female ownership is a key determinant of the likelihood of having a female CEO. In the full-sample estimation with country- and sector-fixed effects (column (2)), the marginal effect reaches 23.7 percentage points. Since $16 \%$ of the firms have a female CEO, ${ }^{11}$ this would correspond to an increase of $39.7 \%$ in the number of female CEOs, which represents an increase of $250 \%$.

[Table 4]

The results in column (3) concern the subsample excluding firms with female sole ownership. Interestingly, these results validate the previous ones: the marginal effect of female ownership participation on the probability of having a female CEO is 20 percentage points, and statistically significant at the $1 \%$ level. Hence, the role played by female owners in increasing the probability of having a female CEO cannot be driven by the firms that have a female ownermanager. In the next specification, we consider the subsample made up of firms with more than five employees, in order to avoid family firms where the owner and the CEO are either the same person or closely related. In column (4) of Table 4, the results line up with the previous ones, thereby strengthening the evidence, and confirming the importance of female ownership participation in utilizing female talent.

While specifications (5) to (7) in Table 4 highlight the fact that ownership features can influence the intensity of the impact of female ownership on the manager's gender, none of them puts the actual significance of the link into question. Column (5) and (6) focus on firms with less than $50 \%$ public ownership and less than 50\% foreign ownership, respectively. Keeping in mind that we are dealing with samples in which the prevalence of female CEOs is $15 \%$ and $16 \%$, respectively (see Table 1), both regressions confirm that female ownership considerably increases the probability of having a woman as CEO. Finally, we explore whether the dispersion

\footnotetext{
${ }^{11}$ See the first column in Table 1.
} 
of ownership has anything to do with the way female ownership influences the presence of a women CEO. The possible channel is that a female has less impact in the shareholder meetings of dispersed firms than in those of closely-held firms. The results reported in Column (7) show that the effect of female ownership resists the limitation to firms with dispersed ownership.

Column (8) goes one step further by imposing all the previous restrictions simultaneously, and so using the sample made up of the 3,525 firms in which it is hardest for a female owner to have a significant impact. Again, the main result comes with a significant marginal effect of 16.4 percentage points. Altogether, our findings suggest a strong link between ownership structure and the likelihood of having a female CEO throughout the developing world.

[Table 5]

In the next step, we try to further understand the nature of the link identified in Table 4 . The regressions reported in Table 5 explore the gendered impact of owners across sectors by means of interaction terms between female ownership and sectors. Interestingly, the impact of female owner(s) on the probability of having a female CEO is similar across all sectors, ${ }^{12}$ except in the garment industry, and in the machinery and equipment sector. These sector-wise differences in female labor force participation can depend on exposure to trade (Juhn et al., 2014; Sauré and Zoabi, 2014).

However, we are more interested in interaction terms between sector dummies and female ownership than in pure sector effects. The regressions reported in Table 5 check whether the gender affinity is either tasted-based or sensitive to information asymmetry, along the lines suggested by Cornell and Welch (1996) and Bostic (2003). Under the common-bond hypothesis, the interaction term should be positive in sectors with greater information asymmetry, which

\footnotetext{
${ }^{12}$ Using the same database, Amin and Islam (2014) examine in greater detail the sector impact on the likelihood of having a female CEO.
} 
are the industries with a lower share of female CEOS. ${ }^{13}$ By contrast, Table 5 reveals that a significantly positive coefficient is found only in the most feminized sector, the garment industry, which has $29 \%$ female CEOs and $51 \%$ female owners. ${ }^{14}$ The interaction is significantly positive in the machinery and equipment sector, which is very masculine. The estimation suggests that the owner-manager gender affinity we observe is tasted-based rather than grounded in common-bond. Moreover, the fact that gender affinity seems to work better in the garment industry is consistent with the idea that a critical mass of women is needed to gain influence and make a difference. In any case, it dismisses the "queen bee syndrome" theory.

\section{Robustness Checks and Extensions}

In this section, we check the robustness of our findings in three directions: adding institutional factors to the specification of Eq. (1), testing the model across jurisdictions, and using alternative measures of female ownership participation.

\subsection{Adding Institutional Factors}

The main message distilled from Tables 4 and 5 is that female ownership is key to explaining the CEO's gender, regardless of the country under consideration, since all of the specifications include country-fixed effects. It could be, however, that the gendered owner-manager interaction is affected by country-specific factors relating to social norms and the institutional framework.

To assess this possibility, we run a new set of regressions and replace country dummies with the country value of the Social Institutions and Gender Index (SIGI). Developed by the OECD,

\footnotetext{
${ }^{13}$ Using the same database, Amin and Islam (2014) examine in greater detail the sector impact on the likelihood of having a female CEO.

${ }^{14}$ See Table A.3 in the Appendix.
} 
SIGI and its specialized sub-indexes ${ }^{15}$ measure discrimination against women in social institutions. SIGI captures how norms, traditions, and codes of conduct shape gender inequalities in education and economic participation. Consequently, it can play a role in mediating the gendered dimension of the owner-manager relationship. SIGI takes values between 0 and 1 , with 0 meaning no (or very low) inequality and 1 representing the maximal level of inequality. Table 6 summarizes the results of the Tobit regressions: in Panel A, we control for the SIGI global index, while the estimations in Panel B use the SIGI Civil Liberties sub-index, which focuses directly on freedom for women's social participation. The findings reported by Amin and Islam (2015) suggest that nondiscrimination clauses in hiring practice effectively increase female employment.

[Table 6]

For the estimations using both indexes, the results are provided in Table 6 with and without the interaction between the index and female ownership participation. These regressions impart several lessons. First, in all specifications the impact of female ownership on the probability that the CEO is a woman is similar to the impact found in country-fixed effect regressions. The significant marginal effect of almost $20 \%$ confirms the robustness of our baseline regressions. Second, the coefficient of the SIGI index is significantly negative at the $1 \%$ level in all specifications, suggesting that social institutions play a role in promoting female talent. The marginal effect stands at -31.2 percentage points in the case of the global index and at $-22.4 \%$ percentage points for the SIGI Civil Liberties sub-index. Interestingly, the SIGI indexes have no significant impact on the owner-manager relationship within firms. Dealing with fairer institutions does not seem to affect the way female shareholders can support same-gender CEOs

\footnotetext{
${ }^{15}$ See Appendix A1 for a detailed description of SIGI and its sub-indexes.
} 
at the firm level. The firm-level gender affinity and the country-level low degree of gender discrimination both help in having female CEOs, but the two factors are not necessarily interconnected.

\subsection{Testing the Model Across Jurisdictions}

Our previous results highlight the importance of countries in our analysis. In the baseline regressions, this dimension is captured through fixed effects. ${ }^{16}$ In subsection 5.1, we replace them with country-level indicators of gender inequality in social institutions. In any case, we observe that jurisdiction matters for promoting female talent in corporations. Here, we assess the regional sensitivity of our results by dividing the countries of interest into four groups: the former Communist bloc, Latin America, Africa, and Asia.

[Table 7]

Table 7 shows that in all cases, the coefficient of female ownership participation is positive and significant at the $1 \%$ level; this once again supports the baseline results that female ownership has an influential role in determining the CEO's gender. In contrast, the marginal effect varies from $11.6 \%$ in Africa to more than $25 \%$ in the former Communist bloc, while Asia and Latin America reach values of around $18 \%$. These results emphasize substantial differences across regions. Possibly, this result relates to the scarcity of females among company owners in Africa.

\subsection{Using Alternative Measures of Female Ownership Participation}

Up to this point, we have measured the presence women shareholders through the "female ownership participation" indicator. However, as argued by Aterido et al. (2013), this indicator

\footnotetext{
${ }^{16}$ See Table 4.
} 
does not account for the shares owned by women and men, respectively. In particular, it fails to distinguish firms with a female minority owner and those with female majority owners.

To circumvent this limitation, we exploit additional information collected by the World Bank Enterprise surveys; specifically, we retrieve the gender of the largest owner and the five-class characterization of ownership into "all men"; "all women"; "male majority"; "female majority”; and "equally divided between men and women." Unfortunately, all these variables are available for African countries only. Table 8 displays the estimation results.

\section{[Table 8]}

Like in previous regressions, the dependent variable is the probability that the CEO is female, and the model includes both country- and sector-fixed effects. To ease comparisons, Table 8 also presents the baseline results obtained for Africa only. Overall, using refined measures of gendered ownership strengthens the relevance of the gender dimension in corporate leadership. The impact of the largest owner being a woman is higher than that of having a least one woman among the owners. More precisely the point estimates pass from 1.070 to 2.222 with a marginal effect gaining $11.7 \%$. This impressive jump suggests that although gender affinity is always present, it can express itself better when female owners are effectively in control. The specification using a five-item classification of gendered ownership highlights the gradual effect in place. The findings are in line with those of Périlleux and Szafarz (2015), who show that in Senegalese financial cooperatives the agenda of women's empowerment is followed more efficiently when the majority of board members are female.

In sum, the robustness checks and extensions confirm that empowering women through access to corporate ownership is not only a way to level the playing field on property rights; it is also a key driver for empowering female talent, and counteracting the "old boys' club" mentality still prevalent in the developing-country corporate world. 


\section{Conclusion}

In the developing world, social norms associated with discriminatory property rights, resulting from unequal inheritance customs, for example, can be solid barriers to female ownership. Despite unfavorable conditions, some women manage to access corporate ownership. In our sample, $40 \%$ of the firms have at least one woman among their owners. By contrast, only $16 \%$ of the same firms have a female CEO. The gender gap in the boardroom raises the suspicion of discriminatory practices and talent under-utilization. This paper scrutinizes the influence of women owners on the ability of firms to attract female CEOs. Its main message is that female ownership contributes to explaining the prevalence of female CEOs, after controlling for other firm and country characteristics. Moreover, the higher the share of female ownership, the stronger its impact. Our results also suggest that the gender affinity we observe relates more to solidarity between women than to informational deficiencies. More broadly, group solidarity in developing countries can be seen as a special case of risk sharing networks, which are most needed when social protection is low (Fafchamps and Gubert, 2007).

Access to the World's Bank's Enterprise Surveys is an exceptional opportunity for researchers on a wide variety of issues relating to firms in developing countries. Interestingly, several of the studies that exploit this database are concerned with corporate corruption (Svensson, 2003; Fisman and Svensson, 2007). Closer to our topic, Ramdani and van Witteloostuijn (2011) show that bribery is more frequent in firms led by women than in those with a male CEO. This observation provides an additional rationale for identifying the factors, such as female ownership, that can boost gender diversity in the boardroom.

From a theoretical perspective, our results can be interpreted as an illustration of the gender affinity hypothesis. Although this hypothesis has been tested at the management level (though mostly in developed countries), its owner-CEO version remains unexplored so far. This is 
probably due to the lack of observations on the sex of corporate owners in developed countries, leaving aside the situation of small firms with little separation between ownership and control.

Aside from pure solidarity stemming from shared identity, gender affinity could also be a rational response to the lack of support given to women leaders by colleagues and subordinates, as observed by Field et al. (2014) in India and by Gagliarducci and Paserman (2014) in Germany. However, further work is needed to assess the motivations of female owners at the firm level.

Moreover, despite all the explanatory variables included in the analysis, it may well be that the common occurrence of female owners and female CEOs is boosted by other factors pertaining, for instance, to the history or structure of the company. Although the possibility of missing variables should always be taken seriously, the fact that our regressions systematically control, in one way or another, for country and sector, and that we investigate several sub-samples separately make it likely that some form of gender affinity really exists. In any case, paying closer attention to the micro-foundations of corporate gender interactions in developing countries opens promising avenues, not only to combat discrimination at the firm level, but also to encourage better utilization of talent, acknowledged as a key determinant of economic development. Gender affinity in corporations could possible bring some kind of "free lunch for development policy”, as Duflo (2012, p.1074) puts it. 


\section{References}

Altonji, J.G., and R.M. Blank (1999). "Race and Gender in Labor Markets", in Ashenfelter, O.A. and D. Card (Eds), Handbook of Labor Economics: Volume 3C, Amsterdam: Elsevier, 3143-3259.

Amin, M. and A. Islam (2014). Are there more Female Managers in the Retail Sector? Evidence from Survey Data in Developing Countries, Journal of Applied Economics, 17(2): 213-228.

Amin, M. and A. Islam (2015). Does Mandating Nondiscrimination in Hiring Practices Influence Women's Employment? Evidence Using Firm-Level Data, Feminist Economics, 21(4): 28-60.

Amore, M.D., O. Garofalo, and A. Minichilli (2014). Gender Interactions within the Family Firm, Management Science, 60(5): 1083-1097.

Aterido, R., Beck, T., and L. Iacovone (2013). Access to Finance in Sub-Saharan Africa: Is there a Gender Gap? World Development, 47: 102-120.

Becker, G.S. (1957). The Economics of Discrimination, Chicago: University of Chicago Press.

Bednar, S. and D. Gicheva (2014). Are Female Supervisors More Female-Friendly? American Economic Review, 104(5): 370-375.

Bell, L.A. (2005). Women-Led Firms and the Gender Gap in Top Executive Jobs, IZA Discussion Papers, No. 1689

Black, S.E., and P.E. Strahan (2001). The Division of Spoils: Rent-Sharing and Discrimination in a Regulated Industry, American Economic Review, 91(4): 814-831.

Blau, F.D., and L.M. Kahn (2000). Gender Differences in Pay, Journal of Economic Perspectives, 14(4): 75-99. 
Bostic, R. (2003). A test of Cultural Affinity in Home Mortgage Lending, Journal of Financial Services Research, 23(2): 8-112.

Brians, C.L. (2005). Women for Women? Gender and Party Bias in Voting for Female Candidates, American Politics Research, 33(3): 357-375.

Bruhn M. (2009). Female-Owned Firms in Latin America Characteristics, Performance, and Obstacles to Growth, Policy Research Working Paper 5122, The World Bank.

Cardoso, A.R., and R. Winter-Ebmer (2010). Female-Led Firms and Gender Wage Policies, Industrial and Labor Relations Review, 64(1): 143-163.

Carter, S. and S. Marlow (2006). Female Entrepreneurship, in Carter, N.M., C. Henry, B.Ó Cinnéide, and K. Johnston (Eds), Female Entrepreneurship: Implications for Education, Training and Policy, Abingdon: Routledge, p. 206-215.

Chander, A. (2003). Minorities, Shareholder and Otherwise, Yale Law Journal, 113: 119-178.

Cornell, B., and I. Welch (1996). Culture, Information, and Screening Discrimination, Journal of Political Economy, 104(3): 542-571.

Das, P. (2014). Women's Participation in Community-Level Water Governance in Urban India: The gap between motivation and ability, World Development, 64: 206-218.

Davidson, M. J., R Burke, A.D. Dillingham, M.A. Ferber, and D.S. Hamermesh (1994). Gender Discrimination by Gender: Voting in a Professional Society, Industrial and Labor Relations Review, 47(4): 622-633.

Dolan, K. (2008). Is There a "Gender Affinity Effect" in American Politics? Information, Affect, and Candidate Sex in U.S. House Elections, American Politics Research, 61(1): 7989. 
Duflo, E. (2012). Women Empowerment and Economic Development. Journal of Economic Literature, 50(4): 1051-1079.

Fafchamps, M. and F. Gubert (2007). The Formation of Risk Sharing Networks, Journal of Development Economics, 83(2): 326-350.

Field, E., S. Jayachandran, R. Pande, and N. Rigol (2014). Friends at Work: Can Peer Support Stimulate Female Entrepreneurship? Working Paper.

Fine, M.G. (2009). Women's Leaders' Discursive Constructions of Leadership. Women's Studies in Communication, 32(2): 180-202.

Fisman, R., and J. Svensson (2007). Are Corruption and Taxation Really Harmful to Growth? Firm Level Evidence, Journal of Development Economics, 83(1): 63-75.

Flabbi, L., M. Macis, A. Moro, and F. Schivardi (2014). Do Female Executives Make a Difference? The Impact of Female Leadership on Gender Gaps and Firm Performance, CEPR DP10228.

Florida, R. (2002). The Economic Geography of Talent, Annals of the Association of American Geographers, 92(4): 743-755.

Gagliarducci, S. and M.D. Paserman (2014) Gender Interactions in Firm Hierarchies: Evidence from Linked Employer-Employee Data, Working Paper.

Gallego, F., and B. Larrain (2012). CEO Compensation and Large Shareholders: Evidence from Emerging Markets, Journal of Comparative Economics, 40: 621-642.

Goldin, C. (2014). A Grand Gender Convergence: Its Last Chapter, American Economic Review, 104(4): 1091-1119. 
Goldin, C., Katz, L.F., and Kuziemko, I. (2006). The Homecoming of American College Women: The Reversal of the Gender Gap in College, Journal of Economic Perspectives, 20(4): 133-156.

Hewlett, S.A., and R. Rashid (2010). The Battle for Female Talent in Emerging Markets. Harvard Business Review, May: 101-106.

Heyman, F., H. Svaleryd, and J. Vlachos (2013). Competition, Takeovers and Gender Discrimination, Industrial and Labor Relations Review, 66(2).

Juhn, C., G. Ujhelyi, and C. Villegas-Sanchez (2014). Men, Women, and Machines: How Trade Impacts Gender Inequality, Journal of Development Economics, 106: 179-193.

Krishnan, H.A., and D. Park (2005). A Few Good Women—on Top Management Teams. Journal of Business Research 58(12): 1712-1720.

Lee, P.M. and E.H. James (2007). She'-E-Os: Gender Effects and Investor Reactions to the Announcements of Top Executive Appointments, Strategic Management Journal, 28: 227241.

Lensink, R. A. Meesters, and I. Naaborg (2008). Bank Efficiency and Foreign Ownership: Do Good Institutions Matter? Journal of Banking and Finance, 32(5): 834-844.

Méon, P.G., and A. Szafarz (2011). The Modern Corporation as a Safe Haven for Taste-Based Discrimination: An Agency Model of Hiring Decisions, Labour Economics, 18(4): 487-497. Muravyev, A., O. Talavera, and D. Schäfer (2009). Entrepreneurs' Gender and Financial Constraints: Evidence from International Data, Journal of Comparative Economics, 37(2): 270-286.Navarro, A.I., and A. Gallo (2014). The Female CEO in Developing Countries' Firms, Working Paper, Universidad Austral.

Navon, G. and I. Tojerow (2013). Does Rent-Sharing Profit Female and Male Workers? 
Evidence from Israeli Matched Employer-Employee Data, Labour, 27(3): 331-349.

Oakley, J.G. (2000). Gender-Based Barriers to Senior Management Positions: Understanding the Scarcity of Female CEOs. Journal of Business Ethics, 27(4): 321-334.

OECD (2014). SIGI Methodological Background Paper, OECD Development Centre, Paris.

Olcott, G. and N. Oliver (2014). The Impact of Foreign Ownership on Gender and Employment Relations in Large Japanese Companies, Work, Employment and Society, 28(2): 206-224.

Pande, R., and D. Ford (2011). Gender Quotas and Female Leadership: A Review, Harvard University, Background Paper for the World Development Report on Gender.

Périlleux, A., and A. Szafarz (2015). Women Leaders and Social Performance: Evidence from Financial Cooperatives in Senegal, World Development, 74: 437-452.

Ramdani, D., and A. van Witteloostuijn (2012). The Shareholder-Manager Relationship and Its Impact on the Likelihood of Firm Bribery, Journal of Business Ethics, 108(4): 495-507.

Rosén, Å. (2003). Search, Bargaining, and Employer Discrimination, Journal of Labor Economics, 21 (4): 807-829.

Rycx, T., and I. Tojerow (2004). Rent Sharing and the Gender Wage Gap in Belgium, International Journal of Manpower, 25(3/4): 279-299.

Sauré, P., and H. Zoabi (2014). International Trade, the Gender Wage Gap and Female Labor Force Participation, Journal of Development Economics, 111: 17-33.

Schuler, R.S., S.E. Jackson, and I. Tarique (2011). Global Talent Management and Global Talent Challenges: Strategic Opportunities for IHRM, Journal of World Business, 46: 50616. 
Sheppard, L.D. and K. Aquino (2014). Sisters in Arms. A Theory of Female Same-Sex Conflict and Its Problematization in Organizations, Journal of Management, doi: $10.1177 / 0149206314539348$.

Siegel, J., L. Pyun, and B.Y. Cheon (2010). Multinational Firms, Labor Market Discrimination, and the Capture of Competitive Advantage by Exploiting the Social Divide, Harvard Business School, Working Paper 11-011.

Smith, N., V. Smith, and M. Verner (2006). Do women in Top Management Affect Firm Performance? A Panel Study of 2,500 Danish Firms. International Journal of Productivity and Performance Management 55(7): 569-593.

Staines, G., C. Tavris, and T. Jayaratne (1974). The Queen Bee Syndrome, Psychology Today, 7(8): 63-66.

Svensson, J. (2003). Who Must Pay Bribes and How Much? Evidence from a Cross Section of Firms, Quarterly Journal of Economics, 118(1): 207-230.

Szafarz, A. (2008). An Alternative to Statistical Discrimination, Economics Bulletin, 10(5): 16.

Vaiman, V., H. Scullion, and D. Collings (2012). Talent Management Decision Making, Management Decision, 50(5): 925-941.

Vishwasrao, S. and W. Bosshardt (2001). Foreign Ownership and Technology Adoption: Evidence from Indian firms, Journal of Development Economics, 65(2): 367-387.

Westphal, J.D. and E.J. Zajac (1995). Who Shall Govern? CEO/Board Power, Demographic Similarity, and New Director Selection, Administrative Science Quarterly, 40(1): 60-83.

Williams, K.Y., and C.A. O’Reilly III (1998). Demography and Diversity in Organizations: A Review of 40 Years of Research, Research in Organizational Behavior, 20: 77-140. 
Table 1: Descriptive Statistics for Firms: Means and Standard Deviations (in Parentheses)

\begin{tabular}{|c|c|c|c|c|c|c|c|}
\hline & All Firms & $\begin{array}{c}\text { No Sole Prop. } \\
\text { with Fem. } \\
\text { Owner }\end{array}$ & $\begin{array}{l}\text { More than } 5 \\
\text { Employees }\end{array}$ & $\begin{array}{l}\text { Public Ownership } \\
<\mathbf{5 0 \%}\end{array}$ & $\begin{array}{c}\text { Foreign Ownership } \\
<\mathbf{5 0 \%}\end{array}$ & $\begin{array}{l}\text { No Owner } \\
>\mathbf{5 0 \%}\end{array}$ & $\begin{array}{c}\text { Female among } \\
\text { owners }\end{array}$ \\
\hline \multicolumn{8}{|l|}{ CEO's Characteristics: } \\
\hline Female & 0.16 & 0.13 & 0.15 & 0.15 & 0.16 & 0.15 & 0.30 \\
\hline \multirow[t]{2}{*}{ Experience (years) } & 18.75 & 18.90 & 19.94 & 19.78 & 20.05 & 20.96 & 20.09 \\
\hline & (11.67) & $(11.70)$ & $(11.85)$ & $(11.85)$ & $(11.96)$ & $(12.11)$ & $(11.96)$ \\
\hline \multicolumn{8}{|l|}{ Ownership characteristics: } \\
\hline Female among owners (yes) & 0.39 & 0.34 & 0.40 & 0.40 & 0.42 & 0.49 & 1.00 \\
\hline Foreign ownership $>50 \%$ & 0.09 & 0.10 & 0.10 & 0.09 & 0.00 & 0.04 & 0.06 \\
\hline Largest Owner $>50 \%$ & 0.65 & 0.65 & 0.65 & 0.65 & 0.63 & 0.00 & 0.58 \\
\hline Public Ownership > 50\% & 0.01 & 0.01 & 0.01 & 0.00 & 0.01 & 0.00 & 0.01 \\
\hline Sole proprietorship & 0.27 & 0.21 & 0.04 & 0.06 & 0.06 & 0.00 & 0.04 \\
\hline \multicolumn{8}{|l|}{ Firm Characteristics: } \\
\hline \multirow[t]{2}{*}{ Size (full-time employees) } & 124.63 & 131.11 & 156.22 & 145.71 & 128.22 & 136.65 & 142.71 \\
\hline & $(661.03)$ & $(682.66)$ & $(733.00)$ & (712.79) & $(679.35)$ & $(521.11)$ & $(899.05)$ \\
\hline \multirow[t]{2}{*}{ Age (years) } & 20.14 & 20.37 & 21.63 & 21.10 & 21.15 & 22.30 & 21.57 \\
\hline & $(17.71)$ & $(17.95)$ & $(18.68)$ & $(18.34)$ & $(18.18)$ & $(18.85)$ & $(18.39)$ \\
\hline \multicolumn{8}{|l|}{ Sector: } \\
\hline Services & 0.44 & 0.44 & 0.41 & 0.43 & 0.43 & 0.40 & 0.43 \\
\hline Manufacturing & 0.56 & 0.56 & 0.59 & 0.57 & 0.57 & 0.60 & 0.57 \\
\hline \multicolumn{8}{|l|}{ Region: } \\
\hline Former Communist Bloc & 0.21 & 0.22 & 0.27 & 0.27 & 0.28 & 0.21 & 0.28 \\
\hline Latin America & 0.40 & 0.41 & 0.48 & 0.47 & 0.47 & 0.52 & 0.41 \\
\hline Africa & 0.18 & 0.18 & 0.06 & 0.06 & 0.05 & 0.06 & 0.07 \\
\hline Asia & 0.21 & 0.19 & 0.20 & 0.20 & 0.20 & 0.21 & 0.24 \\
\hline Number of Firms: & 31541 & 29443 & 18629 & 19685 & 17985 & 6887 & 8038 \\
\hline
\end{tabular}


Table 2: Descriptive Statistics for CEOs: Means \& Standard Deviations (in parentheses)

\begin{tabular}{|c|c|c|c|c|}
\hline & Total & Male CEO & Female CEO & diff. ${ }^{\#}$ \\
\hline $\begin{array}{l}\text { CEO's characteristics: } \\
\text { Experience (years) }\end{array}$ & $\begin{array}{c}18.75 \\
(11.67)\end{array}$ & $\begin{array}{c}19.20 \\
(11.73)\end{array}$ & $\begin{array}{c}16.45 \\
(11.09)\end{array}$ & $\begin{array}{l}2.75^{* * *} \\
(0.18)\end{array}$ \\
\hline $\begin{array}{l}\text { Ownership characteristics: } \\
\text { Female among owners (yes) }\end{array}$ & $\begin{array}{c}0.39 \\
(0.49)\end{array}$ & $\begin{array}{c}0.31 \\
(0.46)\end{array}$ & $\begin{array}{c}0.81 \\
(0.40)\end{array}$ & $\begin{array}{l}-0.49^{* * *} \\
(0.007)\end{array}$ \\
\hline Foreign ownership $>50 \%$ & $\begin{array}{c}0.09 \\
(0.29)\end{array}$ & $\begin{array}{c}0.10 \\
(0.30)\end{array}$ & $\begin{array}{c}0.06 \\
(0.24)\end{array}$ & $\begin{array}{l}0.04^{* * *} \\
(0.004)\end{array}$ \\
\hline Largest owner $>50 \%$ & $\begin{array}{l}0.65 \\
(0.48)\end{array}$ & $\begin{array}{c}0.65 \\
(0.476)\end{array}$ & $\begin{array}{c}0.65 \\
(0.48)\end{array}$ & $\begin{array}{c}0.001 \\
(0.009)\end{array}$ \\
\hline Public ownership $>50 \%$ & $\begin{array}{c}0.01 \\
(0.08)\end{array}$ & $\begin{array}{c}0.01 \\
(0.09)\end{array}$ & $\begin{array}{c}0.01 \\
(0.08)\end{array}$ & $\begin{array}{c}0.002 \\
(0.001)\end{array}$ \\
\hline Sole proprietorship & $\begin{array}{c}0.27 \\
(0.44)\end{array}$ & $\begin{array}{c}0.25 \\
(0.44)\end{array}$ & $\begin{array}{c}0.33 \\
(0.47)\end{array}$ & $\begin{array}{c}-0.08^{* * *} \\
(0.01)\end{array}$ \\
\hline $\begin{array}{l}\text { Firm characteristics: } \\
\text { Size (full-time employees) }\end{array}$ & $\begin{array}{l}124.6 \\
(661.0)\end{array}$ & $\begin{array}{c}135.3 \\
(710.0)\end{array}$ & $\begin{array}{c}70.44 \\
(305.2)\end{array}$ & $\begin{array}{l}64.88^{* * *} \\
(10.04)\end{array}$ \\
\hline Age (years) & $\begin{array}{c}20.14 \\
(17.71)\end{array}$ & $\begin{array}{c}20.56 \\
(18.10)\end{array}$ & $\begin{array}{c}18.00 \\
(15.44)\end{array}$ & $\begin{array}{c}2.57^{* * * *} \\
(0.27)\end{array}$ \\
\hline \multicolumn{5}{|l|}{ Sector: } \\
\hline Services & $\begin{array}{l}0.44 \\
(0.5)\end{array}$ & $\begin{array}{c}0.43 \\
(0.50)\end{array}$ & $\begin{array}{c}0.46 \\
(0.50)\end{array}$ & $\begin{array}{c}-0.03^{* * *} \\
(0.01)\end{array}$ \\
\hline Manufacturing & $\begin{array}{c}0.56 \\
(0.50)\end{array}$ & $\begin{array}{c}0.57 \\
(0.50)\end{array}$ & $\begin{array}{c}0.53 \\
(0.50)\end{array}$ & $\begin{array}{c}0.03^{* * *} \\
(0.01)\end{array}$ \\
\hline \multicolumn{5}{|l|}{ Region: } \\
\hline Former Communist bloc & $\begin{array}{c}0.21 \\
(0.41)\end{array}$ & $\begin{array}{c}0.21 \\
(0.40)\end{array}$ & $\begin{array}{c}0.26 \\
(0.44)\end{array}$ & $\begin{array}{c}-0.05^{* * * *} \\
(0.01)\end{array}$ \\
\hline Latin America & $\begin{array}{c}0.40 \\
(0.49)\end{array}$ & $\begin{array}{c}0.41 \\
(0.49)\end{array}$ & $\begin{array}{c}0.35 \\
(0.48)\end{array}$ & $\begin{array}{c}0.06^{* * *} \\
(0.01)\end{array}$ \\
\hline Africa & $\begin{array}{c}0.18 \\
(0.23)\end{array}$ & $\begin{array}{c}0.19 \\
(0.39)\end{array}$ & $\begin{array}{c}0.15 \\
(0.35)\end{array}$ & $\begin{array}{c}0.04^{* * * *} \\
(0.01)\end{array}$ \\
\hline Asia & $\begin{array}{c}0.20 \\
(0.41)\end{array}$ & $\begin{array}{c}0.20 \\
(0.40)\end{array}$ & $\begin{array}{c}0.24 \\
(0.43)\end{array}$ & $\begin{array}{c}-0.04^{* * *} \\
(0.01)\end{array}$ \\
\hline
\end{tabular}

\# Results from t-tests for equal means (standard errors in parentheses): $\left.{ }^{*} p<0.05,{ }^{* *} p<0.01,{ }^{* * *} p<0.001\right)$. 
Table 3: Descriptive Statistics for Gendered Leadership by Country: Means \& Standard Deviations (in parentheses)

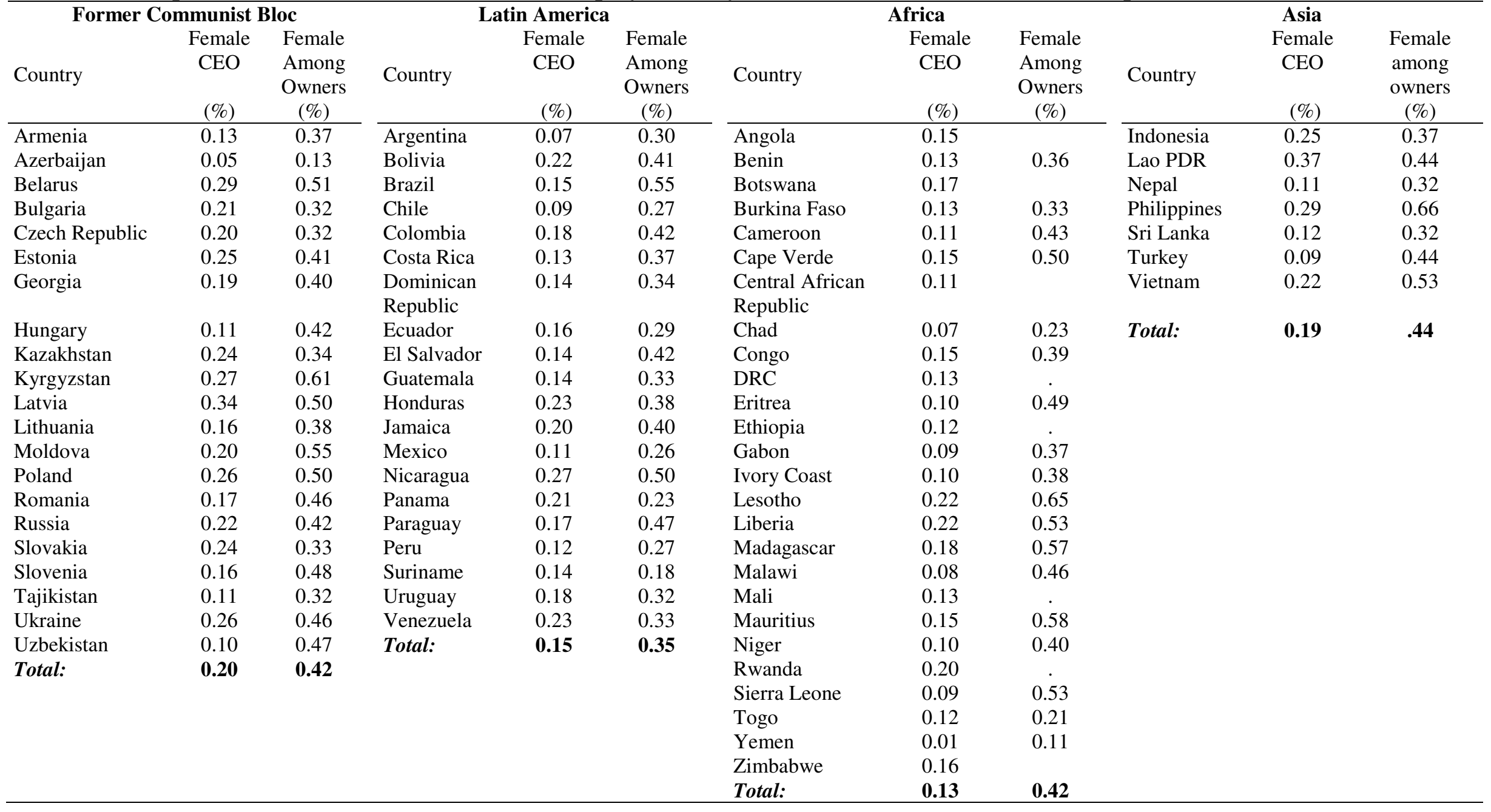


Table 4: Female CEO and Female Ownership: Probit Regressions

\begin{tabular}{|c|c|c|c|c|c|c|c|c|}
\hline Dependent variable: female CEO & $(1)$ & (2) & (3) & (4) & $(5)$ & $(6)$ & (7) & (8) \\
\hline \multicolumn{9}{|c|}{ Selected estimates (t-statistics in parentheses) } \\
\hline Female among owners & $\begin{array}{c}1.225 \\
(59.233)^{* * *}\end{array}$ & $\begin{array}{c}1.209 \\
(54.942)^{* * *}\end{array}$ & $\begin{array}{c}1.051 \\
(44.729)^{* * *}\end{array}$ & $\begin{array}{c}1.031 \\
(39.326)^{* * *}\end{array}$ & $\begin{array}{c}1.092 \\
(42.966)^{* * *}\end{array}$ & $\begin{array}{c}1.141 \\
(41.999)^{* * *}\end{array}$ & $\begin{array}{c}0.851 \\
(13.6)^{* * * *}\end{array}$ & $\begin{array}{c}0.855 \\
(12.894)^{* * *}\end{array}$ \\
\hline CEO's experience & $\begin{array}{c}-0.015 \\
(-17.424)^{* * *}\end{array}$ & $\begin{array}{c}-0.012 \\
(-12.83)^{* * *}\end{array}$ & $\begin{array}{c}-0.013 \\
(-12.027)^{* * *}\end{array}$ & $\begin{array}{c}-0.012 \\
(10.119)^{* * *}\end{array}$ & $\begin{array}{c}-0.012 \\
(11.015)^{* * *}\end{array}$ & $\begin{array}{c}-0.012 \\
(10.462) * * *\end{array}$ & $\begin{array}{c}-0.007 \\
(2.871)^{* * *}\end{array}$ & $\begin{array}{c}-0.006 \\
(2.499) * * *\end{array}$ \\
\hline \multicolumn{9}{|l|}{ Marginal effect } \\
\hline Female among owners & 0.255 & 0.237 & 0.185 & 0.195 & 0.210 & 0.221 & 0.163 & 0.164 \\
\hline CEO's experience & -0.003 & -0.002 & -0.002 & -0.002 & -0.002 & -0.002 & -0.001 & -0.001 \\
\hline Country-fixed effects & No & Yes & Yes & Yes & Yes & Yes & Yes & Yes \\
\hline Sector-fixed effects & No & Yes & Yes & Yes & Yes & Yes & Yes & Yes \\
\hline Number of observations & 27061 & 27061 & 25007 & 19508 & 20547 & 18574 & 3887 & 3525 \\
\hline Number of positive observations & 4542 & 4542 & 3348 & 2858 & 3171 & 2943 & 554 & 507 \\
\hline Fraction of correct predictions & $83 \%$ & $84 \%$ & $87 \%$ & $86 \%$ & $85 \%$ & $85 \%$ & $86 \%$ & $86 \%$ \\
\hline
\end{tabular}

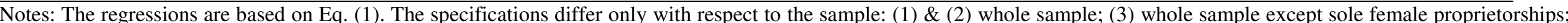

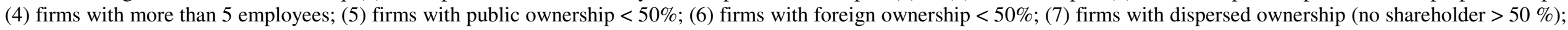

(8) firms fulfilling all the previous constraints altogether.

The full results for specification (2) \& (3) are provided in Table A.4 in the Appendix. T-stat in parentheses; ${ }^{*} p<0.05,{ }^{* *} p<0.01,{ }^{* * *} p<0.001$. 
Table 5: Female CEO and Female Ownership: Sectoral Interactions

\begin{tabular}{|c|c|c|c|}
\hline \multirow{2}{*}{ Dependent variable: female CEO } & \multicolumn{3}{|c|}{ (9) } \\
\hline & Coefficient & T-statistic & Marginal effect \\
\hline Female among owners & $1.021 * * *$ & 15.748 & 0.179 \\
\hline CEO's experience & $-0.013 * * *$ & -11.993 & -0.002 \\
\hline \multicolumn{4}{|l|}{ Sectors } \\
\hline Textiles & -0.106 & -1.062 & -0.019 \\
\hline Garments & $0.151 *$ & 1.939 & 0.027 \\
\hline Chemicals & 0.066 & 0.763 & 0.012 \\
\hline Plastics \& rubber & $-0.281 * * *$ & -3.277 & -0.049 \\
\hline Basic metals & $-0.169^{*}$ & -1.953 & -0.030 \\
\hline Fabricate metal products & $-0.966^{* * *}$ & -3.522 & -0.170 \\
\hline Non-metallic mineral products & $-0.270 *$ & -1.829 & -0.047 \\
\hline Machinery and equipment & 0.090 & 0.658 & 0.016 \\
\hline Electronics & $-0.223^{* * *}$ & -2.884 & -0.039 \\
\hline Construction & $-0.214 * *$ & -2.253 & -0.038 \\
\hline Transport & $-0.515^{* * *}$ & -2.917 & -0.090 \\
\hline Hotel and restaurants & $0.393 * * *$ & 4.564 & 0.069 \\
\hline IT & -0.355 & -1.380 & -0.062 \\
\hline Retail & 0.073 & 1.250 & 0.013 \\
\hline Wholesale & $-0.353 * *$ & -2.513 & -0.062 \\
\hline Other services & -0.074 & -0.914 & -0.013 \\
\hline \multicolumn{4}{|c|}{$\begin{array}{l}\text { Interactions between "Female among owners" and Sectors } \\
\text { Manufacturing: }\end{array}$} \\
\hline Textiles & 0.141 & 1.090 & 0.025 \\
\hline Garments & $0.320 * * *$ & 3.184 & 0.056 \\
\hline Chemicals & -0.026 & -0.229 & -0.005 \\
\hline Plastics \& rubber & 0.019 & 0.167 & 0.003 \\
\hline Basic metals & -0.010 & -0.087 & -0.002 \\
\hline Fabricate metal products & 0.465 & 1.515 & 0.082 \\
\hline Non-metallic mineral products & $-0.355^{*}$ & -1.774 & -0.062 \\
\hline Machinery and equipment & $-0.655 * * *$ & -3.149 & -0.115 \\
\hline \multicolumn{4}{|l|}{ Services: } \\
\hline Electronics & -0.021 & -0.211 & -0.004 \\
\hline Construction & -0.198 & -1.531 & -0.035 \\
\hline Transport & -0.193 & -0.801 & -0.034 \\
\hline Hotel and restaurants & -0.112 & -0.933 & -0.020 \\
\hline IT & -0.013 & -0.038 & -0.002 \\
\hline Retail & 0.105 & 1.347 & 0.018 \\
\hline Wholesale & 0.245 & 1.359 & 0.043 \\
\hline Other services & $-0.193 *$ & -1.711 & -0.034 \\
\hline Constant & $-1.563 * * *$ & -12.087 & \\
\hline Number of observations & & 25007 & \\
\hline Number of positive observations & & 3348 & \\
\hline Fraction of correct predictions & & $87 \%$ & \\
\hline
\end{tabular}

Notes: The probit regressions include country and sector fixed effects. Armenia and food are the references. ${ }^{*} p<$ $0.05,{ }^{* *} p<0.01,{ }^{* * *} p<0.001$. 
Table 6: Female CEO and Female Ownership: SIGI Index

\begin{tabular}{|c|c|c|c|c|c|c|}
\hline \multirow{2}{*}{$\begin{array}{l}\text { Dependent variable: } \\
\text { female CEO }\end{array}$} & \multicolumn{3}{|c|}{$(10)$} & \multicolumn{3}{|c|}{ (11) } \\
\hline & Coef. & T-Stat. & $\begin{array}{c}\text { Marginal } \\
\text { effect }\end{array}$ & Coef. & T-Stat. & $\begin{array}{c}\text { Marginal } \\
\text { effect }\end{array}$ \\
\hline \multicolumn{7}{|l|}{ Panel A. global index } \\
\hline Female among owners & $1.063 * * *$ & 40.22 & 0.196 & $1.074 * * *$ & 33.811 & 0.198 \\
\hline CEO's experience & $-0.015^{* * *}$ & -13.00 & -0.003 & $-0.015 * * *$ & -12.984 & -0.003 \\
\hline SIGI index & $-1.698 * * *$ & -8.83 & -0.312 & $-1.586 * * *$ & -5.921 & -0.292 \\
\hline \multicolumn{4}{|c|}{ SIGI index X female among owners } & -0.221 & -0.590 & -0.041 \\
\hline Sector-fixed effects & \multicolumn{3}{|c|}{ Yes } & \multicolumn{3}{|c|}{ Yes } \\
\hline Number of observations & \multicolumn{3}{|c|}{17840} & \multicolumn{3}{|c|}{17840} \\
\hline $\begin{array}{l}\text { Number of positive } \\
\text { observations }\end{array}$ & \multicolumn{3}{|c|}{2464} & \multicolumn{3}{|c|}{2464} \\
\hline Fraction of correct predictions & \multicolumn{3}{|c|}{$86 \%$} & \multicolumn{3}{|c|}{$86 \%$} \\
\hline
\end{tabular}

\section{Panel B. Civil Liberties sub-index}

$\begin{array}{lcccccc}\text { Female among owners } & 1.036 * * * & 40.252 & 0.192 & 1.048 * * * & 39.198 & 0.194 \\ \text { CEO's experience } & -0.015 * * * & -12.845 & -0.003 & -0.015 * * * & -12.854 & -0.003 \\ \text { SIGI index } & -1.212 * * * & -9.610 & -0.224 & -1.024 * * * & -6.411 & -0.189 \\ \text { SIGI index X female among owners } & & & -0.437 * & -1.754 & -0.081\end{array}$

$\begin{array}{lll}\text { Sector-fixed effects } & \text { Yes } & \text { Yes }\end{array}$

\begin{tabular}{lcc}
\hline $\begin{array}{l}\text { Number of observations } \\
\text { Number of positive }\end{array}$ & 18631 & 18631 \\
$\begin{array}{l}\text { observations } \\
\text { Fraction of correct predictions }\end{array}$ & 2577 & 2577 \\
\hline
\end{tabular}

Notes: The probit regressions include sectoral dummies. The SIGI global index and its Civil Liberties sub-index replace country dummies, respectively. The values of both indexes are between 0 and 1 , where 0 means no inequality and 1is the highest inequality. ${ }^{*} p<0.05,{ }^{* *} p<0.01,{ }^{* * *} p<0.001$. 
Table 7: Female CEO and Female Ownership, by Region: Probit Regressions

\begin{tabular}{|c|c|c|c|c|c|c|}
\hline \multirow{2}{*}{$\begin{array}{l}\text { Dependent variable: } \\
\text { female CEO }\end{array}$} & \multicolumn{3}{|c|}{ (12) } & \multicolumn{3}{|c|}{ (13) } \\
\hline & Coef. & t-Stat. & $\begin{array}{c}\text { Marginal } \\
\text { effect }\end{array}$ & Coef. & t-Stat. & $\begin{array}{c}\text { Marginal } \\
\text { effect }\end{array}$ \\
\hline Regions: & \multicolumn{3}{|c|}{ Former Communist } & \multicolumn{3}{|c|}{ Latin America } \\
\hline Female among owners & $1.210 * * *$ & 26.795 & 0.254 & $1.012 * * *$ & 30.108 & 0.176 \\
\hline CEO's experience & $-0.005^{* *}$ & -2.183 & -0.001 & $-0.018 * * *$ & -12.238 & -0.003 \\
\hline Number of observations & \multicolumn{3}{|c|}{5689} & \multicolumn{3}{|c|}{11184} \\
\hline $\begin{array}{l}\text { Number of positive } \\
\text { observations }\end{array}$ & \multicolumn{3}{|c|}{1053} & \multicolumn{3}{|c|}{1383} \\
\hline $\begin{array}{l}\text { Fraction of correct } \\
\text { predictions }\end{array}$ & \multicolumn{3}{|c|}{$83 \%$} & \multicolumn{3}{|c|}{$88 \%$} \\
\hline & \multicolumn{3}{|c|}{ (14) } & \multicolumn{3}{|c|}{$(15)$} \\
\hline Regions: & \multicolumn{3}{|c|}{ Africa } & \multicolumn{3}{|c|}{ Asia } \\
\hline Female among owners & $0.828 * * *$ & 9.649 & 0.116 & $1.054 * * *$ & 21.561 & 0.188 \\
\hline CEO's experience & $-0.017 * * *$ & -3.875 & -0.002 & $-0.016 * * *$ & -7.463 & -0.003 \\
\hline Number of observations & \multicolumn{3}{|c|}{2080} & \multicolumn{3}{|c|}{5394} \\
\hline $\begin{array}{l}\text { Number of positive } \\
\text { observations }\end{array}$ & \multicolumn{3}{|c|}{180} & \multicolumn{3}{|c|}{679} \\
\hline $\begin{array}{l}\text { Fraction of correct } \\
\text { predictions }\end{array}$ & \multicolumn{3}{|c|}{$91 \%$} & \multicolumn{3}{|c|}{$87 \%$} \\
\hline
\end{tabular}

predictions

Note: The regressions include sector-fixed effects. ${ }^{*} p<0.05,{ }^{* *} p<0.01,{ }^{* * *} p<0.001$. 
Dependent variable: female CEO

Female among owners

(14)

1.070

$(13.416)^{* * * *}$

The largest owner is a woman

Owners of the firm

All women

Female majority

Male majority

All men

CEO's experience

\section{Marginal effects:}

Female among owners

The largest owner is a woman

Owners of the firm:

All women

$-0.018$

$(4.521)^{* * *}$

$-0.018$

$(2.777)^{* * *}$

$-0.013$

$(2.983)^{* * *}$

Female majority

Male majority

0.122

All men

$-0.140$

CEO's experience

$-0.003$

$-0.002$

$-0.002$

\begin{tabular}{lccc}
\hline Number of observations & 2386 & 1015 & 2374 \\
Number of positive observations & 298 & 176 & 297 \\
Fraction of correct predictions & $88 \%$ & $91 \%$ & $91 \%$ \\
\hline
\end{tabular}

Note: The probit regressions are run on the subsample made of the 17 African countries reported in Table 1. The specifications differ in the way female ownership is captured: (1) same as in previous estimations; (2) dummy for female largest owner; (3) five dummies with the reference being "ownership equally divided between men and women.

T-stat in parentheses; ${ }^{*} p<0.05,{ }^{* *} p<0.01,{ }^{* * *} p<0.001$. 


\section{Appendix: Additional Tables}

Table A1: Sample Composition

\begin{tabular}{|c|c|c|c|c|c|c|c|}
\hline \multicolumn{2}{|c|}{$\begin{array}{c}\text { Former Communist } \\
\text { Bloc }\end{array}$} & \multicolumn{2}{|c|}{ Latin America } & \multicolumn{2}{|l|}{ Africa } & \multicolumn{2}{|c|}{ Asia } \\
\hline Country & Obs. & Country & Obs. & Country & Obs. & Country & Obs. \\
\hline Armenia* & 252 & Argentina $^{\$}$ & 1028 & Angola $\$$ & 351 & Indonesia* & 1426 \\
\hline Azerbaijan* & 348 & Bolivia $\$$ & 353 & Benin* & 149 & $\mathrm{Lao} \mathrm{PDR}^{+}$ & 230 \\
\hline Belarus* & 272 & Brazil* $^{*}$ & 1790 & Botswana $\$$ & 268 & Nepal* & 368 \\
\hline Bulgaria* & 225 & Chile $^{\$}$ & 1015 & Burkina Faso* & 392 & Philippines* & 1288 \\
\hline Czech Rep.* & 179 & Colombia $^{\$}$ & 929 & Cameroon* & 363 & Sri Lanka $\%$ & 593 \\
\hline Estonia* & 246 & Costa Rica ${ }^{\$}$ & 527 & Cape Verde* & 155 & Turkey ${ }^{\#}$ & 1138 \\
\hline Georgia* & 367 & Dominican Rep. $\$$ & 354 & Central African R.\% & 150 & Vietnam* & 1049 \\
\hline Hungary* & 270 & Ecuador $\$$ & 360 & Chad* $^{*}$ & 150 & Yemen $\$$ & 472 \\
\hline Kazakhstan* & 411 & El Salvador $\$$ & 355 & Congo*\$ & 440 & & \\
\hline Kyrgyzstan* & 176 & Guatemala $^{\$}$ & 578 & Eritrea* & 178 & & \\
\hline Latvia* & 232 & Honduras $\$$ & 354 & Ethiopia\% & 639 & & \\
\hline Lithuania* & 222 & Jamaica $^{\$}$ & 353 & Gabon* & 77 & & \\
\hline Moldova* & 347 & Mexico $^{\$}$ & 1459 & Ivory Coast* & 178 & & \\
\hline Poland* & 254 & Nicaragua $^{\$}$ & 328 & Lesotho* & 81 & & \\
\hline Romania* & 306 & Panama $\$$ & 361 & Liberia* & 45 & & \\
\hline Russia* & 657 & Paraguay $^{\$}$ & 360 & Madagascar* & 219 & & \\
\hline Slovakia* & 174 & $\mathrm{Peru}^{\$}$ & 995 & Malawi* & 150 & & \\
\hline Slovenia* & 255 & Suriname $^{\$}$ & 152 & Mali $^{\$}$ & 358 & & \\
\hline Tajikistan* & 353 & Uruguay $^{\$}$ & 586 & Mauritius* & 185 & & \\
\hline Ukraine* & 831 & Venezuela $^{\$}$ & 297 & Niger* & 150 & & \\
\hline \multirow[t]{4}{*}{ Uzbekistan* } & 362 & & & Rwanda $\%$ & 232 & & \\
\hline & & & & Sierra Leone* & 47 & & \\
\hline & & & & Togo* & 155 & & \\
\hline & & & & Zimbabwe $\%$ & 592 & & \\
\hline Total: & 6739 & & 12534 & & 5704 & & 6564 \\
\hline
\end{tabular}

Note: Sample year: ${ }^{\#} 2008, * 2009,{ }^{\$} 2010,{ }^{\%} 2011,{ }^{+} 2012$. 
Table A2: Description of the Firm Characteristics

\begin{tabular}{|c|c|}
\hline Variable & Description \\
\hline \multicolumn{2}{|l|}{ World Bank Enterprise Surveys: } \\
\hline \multicolumn{2}{|l|}{ CEO: } \\
\hline Female CEO & Is the top manager female? "yes" / "no" \\
\hline CEO's experience & Years of professional experience \\
\hline \multicolumn{2}{|l|}{ Ownership: } \\
\hline Female among owners & Are any of the owners female? "yes" / "no" \\
\hline Female largest owner ${ }^{+}$ & Is the largest owner female? "yes" / "no" \\
\hline Gender ownership structure $(1 / 5):^{+}$all men & Are the owners of the firm all men? "yes" / "no" \\
\hline Gender owner. struct. (2/5): ${ }^{+}$all women & Are the owners of the firm all women? "yes" / "no" \\
\hline Gender owner. struct. (3/5): ${ }^{+}$majority of w. & Are the majority of owners of the firm women? "yes" / "no" \\
\hline Gender owner. struct. (4/5): ${ }^{+}$majority of men & Are the majority of owners of the firm men? "yes" / "no" \\
\hline Gender owner. struct. (5/5): $:^{+}$equally divided & $\begin{array}{l}\text { Are the owners of the firm equally divided between women } \\
\text { and men? "yes" / "no" }\end{array}$ \\
\hline Ownership concentration & Share of the largest owner $(\%)$ \\
\hline Ownership composition (1/4): private & Share of private national owners $(\%)$ \\
\hline Ownership composition (2/4): foreign & Share of private foreign owners $(\%)$ \\
\hline Ownership composition (3/4): public & Share of public sector as owner (\%) \\
\hline Ownership composition (4/4): other & Share of other owner $(\%)$ \\
\hline Industry affiliation & $\begin{array}{l}\text { Manufacturing: Food, Textiles, Garments, Chemicals, Plastics } \\
\& \text { rubber, Basic metals, Fabricate metal products, Non- } \\
\text { metallic mineral products, Machinery and equipment, } \\
\text { Electronics (10). Services: Construction, Transport, Hotel and } \\
\text { restaurants, IT, Retail, Wholesale, Other services (7) }\end{array}$ \\
\hline Legal status & $\begin{array}{l}\text { Publicly listed company; Private held, limited liability } \\
\text { company; Sole proprietorship; Partnership; Limited } \\
\text { partnership }\end{array}$ \\
\hline Size & $\begin{array}{l}\text { How many permanent, full-time employees did you have last } \\
\text { year? }\end{array}$ \\
\hline
\end{tabular}

OECD (Social Institutions and Gender Index (SIGI): \%

The indexes take values between 0 and 1: 0 means no or very low inequality, 1 indicates very high inequality.

global index

Civil liberties sub-index
Instead of measuring gender inequalities in education, health, economic or political participation and other dimensions, the SIGI measures important inputs - social institutions - to such outcome inequalities in non-OECD countries. These social institutions are conceived as long-lasting codes of conduct, norms, traditions, informal and formal laws. It is composed of five sub-indices: Family Code, Restricted Resources and Assets, Civil Liberties, Physical Integrity, and Son Preference (OECD, 2014).

The Civil Liberties sub index of the SIGI global index, it captures the freedom of social participation of women and includes the following variables. Freedom of Movement indicates the freedom of women to move outside the home. Freedom of Dress is based on the obligation of women to follow a certain dress code, for example to cover parts of their body in the public (OECD, 2014).

Notes: ${ }^{\%}$ See genderindex.org for more details. ${ }^{+}$Variable only for African countries 
Sectors

Female CEO

$(\%)$

0.17

0.20

0.29

0.17

0.12

0.08

0.06

0.12

0.07

Machinery and equipment

\section{Services:}

Electronics

Construction

Transport

Hotel and restaurants

IT

Retail

Wholesale

Other services
0.11

0.33

0.09

0.34

0.06

0.32

0.25

0.42

0.09

0.36

0.21

0.42

0.15

0.36

0.10

0.32 
Table A4: Female CEO and Ownership Structure: Probit Regressions

\begin{tabular}{lcccc}
\hline Dependent variable: female CEO & \multicolumn{2}{c}{ All firms } & \multicolumn{2}{c}{ Except sole female owner } \\
& Coefficient & t-statistic & Coefficient & t-statistic \\
\hline & & & & \\
Female among owners & 1.209 & 54.942 & 1.051 & 44.729 \\
CEO's experience & -0.012 & -12.830 & -0.013 & -12.027
\end{tabular}

Country-fixed effects (ref.: Armenia)

\section{Former Communist Block:}

Azerbaijan

Belarus

Bulgaria

Czech Republic

Estonia

Georgia

Hungary

Kazakhstan

Kyrgyzstan

Latvia

Lithuania

Moldova

Poland

Romania

Russia

Slovakia

Slovenia

Tajikistan

Ukraine

Uzbekistan

$\begin{array}{cccc}-0.118 & -0.676 & -0.188 & -1.020 \\ 0.597 * * * & 4.048 & 0.592 * * * & 3.840 \\ 0.585 * * * & 3.664 & 0.480 * * * & 2.862 \\ 0.645 * * * & 3.870 & 0.656 * * * & 3.772 \\ 0.639 * * * & 4.163 & 0.672 * * * & 4.350 \\ 0.363 * * & 2.480 & 0.312 * * & 2.065 \\ 0.035 & 0.213 & 0.070 & 0.415 \\ 0.623 * * * & 4.425 & 0.614 * * * & 4.288 \\ 0.466 * * * & 2.896 & 0.510 * * * & 3.111 \\ 0.820 * * * & 5.415 & 0.871 * * * & 5.683 \\ 0.227 & 1.391 & 0.166 & 0.970 \\ 0.210 & 1.456 & 0.225 & 1.522 \\ 0.595 * * * & 3.847 & 0.514 * * * & 3.101 \\ 0.197 & 1.276 & 0.249 & 1.600 \\ 0.454 * * * & 3.394 & 0.488 * * * & 3.600 \\ 0.705 * * * & 4.225 & 0.697 * * * & 4.084 \\ 0.278 * & 1.774 & 0.322 * * & 2.032 \\ 0.047 & 0.307 & 0.053 & 0.336 \\ 0.540 * * * & 4.161 & 0.491 * * * & 3.640 \\ -0.238 & -1.564 & -0.281 * & -1.714\end{array}$

Latin America:

Brazil

Argentina

Bolivia

Chile

Colombia

Costa Rica

Dominican Republic

Ecuador

El Salvador

Guatemala

Honduras

Jamaica

Mexico

Nicaragua

Panama

Paraguay

Peru

Suriname

Uruguay

Venezuela

$\begin{array}{cccc}0.019 & 0.147 & 0.084 & 0.637 \\ -0.175 & -1.275 & -0.159 & -1.136 \\ 0.408 * * * & 2.822 & 0.317 * * & 2.064 \\ 0.040 & 0.295 & 0.009 & 0.064 \\ 0.313 * * & 2.410 & 0.350 * * * & 2.643 \\ 0.079 & 0.564 & 0.101 & 0.707 \\ 0.204 & 1.375 & 0.245 & 1.628 \\ 0.377 * * & 2.579 & 0.411 * * * & 2.785 \\ 0.079 & 0.531 & 0.110 & 0.719 \\ 0.153 & 1.107 & 0.114 & 0.790 \\ 0.516 * * * & 3.600 & 0.415 * * * & 2.752 \\ 0.307 * * & 2.079 & 0.217 & 1.396 \\ 0.219 * & 1.709 & 0.143 & 1.075 \\ 0.562 * * * & 3.918 & 0.317 * & 1.977 \\ 0.529 * * * & 3.711 & 0.525 * * * & 3.628 \\ 0.167 & 1.135 & 0.244 & 1.643 \\ 0.165 & 1.253 & 0.165 & 1.225 \\ 0.471 * * * & 2.621 & 0.480 * * & 2.550 \\ 0.404 * * * & 2.980 & 0.411 * * * & 2.964 \\ 0.544 * * * & 3.720 & 0.571 * * * & 3.837 \\ & & & \\ 0.037 & 0.181 & -0.546 * & -1.905 \\ -0.043 & -0.212 & -0.154 & -0.667 \\ 0.150 & 0.603 & 0.194 & 0.689 \\ -0.289 & -1.439 & -0.353 & -1.587 \\ -0.131 & -0.474 & -0.253 & -0.805 \\ -0.128 & -0.670 & -0.208 & -0.918\end{array}$

Africa:

Benin

Chad

Congo

Eritrea

Gabon

Ivory Coast 


\begin{tabular}{|c|c|c|c|c|}
\hline Lesotho & 0.202 & 0.978 & 0.279 & 1.327 \\
\hline Liberia & $0.429 *$ & 1.661 & 0.416 & 1.585 \\
\hline Madagascar & 0.011 & 0.067 & -0.031 & -0.183 \\
\hline Mauritius & -0.092 & -0.524 & 0.009 & 0.048 \\
\hline Sierra Leone & -0.310 & -1.097 & -0.236 & -0.827 \\
\hline Togo & 0.216 & 1.090 & 0.107 & 0.495 \\
\hline Malawi & $-0.383^{*}$ & -1.883 & $-0.503 * *$ & -2.122 \\
\hline Burkina Faso & 0.118 & 0.761 & -0.002 & -0.010 \\
\hline Niger & $-0.535^{*}$ & -1.891 & -0.352 & -1.235 \\
\hline Cameroon & -0.169 & -1.103 & $-0.374 * *$ & -2.083 \\
\hline Cape Verde & 0.093 & 0.513 & 0.083 & 0.411 \\
\hline \multicolumn{5}{|l|}{ Asia: } \\
\hline Indonesia & $0.571 * * *$ & 4.559 & $0.368 * * *$ & 2.783 \\
\hline Lao PDR & $0.774 * * *$ & 5.070 & -0.097 & -0.408 \\
\hline Nepal & -0.034 & -0.223 & -0.071 & -0.447 \\
\hline Philippines & $0.440 * * *$ & 3.524 & $0.417 * * *$ & 3.239 \\
\hline Sri Lanka & -0.070 & -0.498 & $-0.329 * *$ & -2.096 \\
\hline Turkey & -0.170 & -1.295 & -0.108 & -0.808 \\
\hline Vietnam & $0.232 *$ & 1.816 & 0.174 & 1.321 \\
\hline Yemen & $-0.905 * * *$ & -4.024 & $-0.996 * * *$ & -3.933 \\
\hline \multicolumn{5}{|c|}{ Sector-fixed effects (ref.: food sector) } \\
\hline \multicolumn{5}{|c|}{ Manufacturing: } \\
\hline Textiles & 0.040 & 0.715 & -0.024 & -0.374 \\
\hline Garments & $0.350 * * *$ & 7.993 & $0.347 * * *$ & 7.124 \\
\hline Chemicals & -0.030 & -0.568 & 0.049 & 0.866 \\
\hline Plastics \& rubber & $-0.315 * * *$ & -6.102 & $-0.267 * * *$ & -4.674 \\
\hline Basic metals & $-0.240 * * *$ & -4.250 & $-0.173^{* * *}$ & -2.880 \\
\hline Fabricate metal products & $-0.700 * * *$ & -5.847 & $-0.631 * * *$ & -5.253 \\
\hline Non-metallic mineral products & $-0.558 * * *$ & -5.399 & $-0.483 * * *$ & -4.596 \\
\hline Machinery and equipment & $-0.297 * * *$ & -2.813 & $-0.207 *$ & -1.919 \\
\hline Electronics & $-0.290 * * *$ & -6.137 & $-0.238 * * *$ & -4.652 \\
\hline \multicolumn{5}{|l|}{ Services: } \\
\hline Construction & $-0.418 * * *$ & -6.545 & $-0.325 * * *$ & -4.865 \\
\hline Transport & $-0.718 * * *$ & -5.848 & $-0.627 * * *$ & -5.045 \\
\hline Hotel and restaurants & $0.293 * * *$ & 5.255 & $0.339 * * *$ & 5.531 \\
\hline IT & $-0.393 * *$ & -2.479 & $-0.376 * *$ & -2.257 \\
\hline Retail & 0.111 & 3.113 & $0.130 * * *$ & 3.303 \\
\hline Wholesale & $-0.292 * * *$ & -3.337 & $-0.218 * *$ & -2.410 \\
\hline Other services & $-0.269 * * *$ & -4.960 & $-0.169 * * *$ & -2.925 \\
\hline Constant & $-1.593 * * *$ & -13.047 & $-1.578 * * *$ & -12.598 \\
\hline Number of observations & \multicolumn{2}{|c|}{27061} & \multicolumn{2}{|c|}{25007} \\
\hline Number of positive observations & \multicolumn{2}{|c|}{4542} & \multicolumn{2}{|c|}{3348} \\
\hline Fraction of correct predictions & \multicolumn{2}{|c|}{$84 \%$} & \multicolumn{2}{|c|}{$87 \%$} \\
\hline
\end{tabular}

Note: The probit regressions are based on Eq. (1). Specification (1) is for the full sample; Specification (2) excludes the sole proprietorship firms with a female owner. ; ${ }^{*} p<0.05,{ }^{* *} p<0.01,{ }^{* * *} p<0.001$. 